\title{
Pre-Columbian human occupation of Amazonia and its influence on current landscapes and biodiversity
}

\author{
DOYLE MCKEY \\ Centre d'Ecologie Fonctionnelle et Evolutive/CEFE, CNRS, University of Montpellier, University \\ Paul Valéry Montpellier 3, EPHE, IRD, 1919 route de Mende, 34293, Montpellier, France \\ Manuscript received on January 25, 2019; accepted for publication on June 17, 2019
}

\begin{abstract}
How to cite: MCKEY D. 2019. Pre-Columbian human occupation of Amazonia and its influence on current landscapes and biodiversity. An Acad Bras Cienc 91: e20190087. DOI 10.1590/0001-3765201920190087.

Abstract: There is growing evidence that pre-Columbian humans had strong impacts on soils, plant and animal communities and ecosystem functioning in many parts of Amazonia, and that the legacies of these impacts still affect biodiversity and how ecosystems function today. Understanding the history of human/ environment interactions in Amazonia is essential for analyzing the current state of these interactions and imagining scenarios for the future. This study gives a brief overview of these themes.
\end{abstract}

Key words: Amazonian Dark Earths, ecological legacy, historical ecology, Pleistocene megafaunal extinctions, pre-Columbian raised fields.

\section{INTRODUCTION}

The focus of this paper is primarily on the forests, savannas and rivers of the Amazon Basin, but some examples are drawn from 'greater Amazonia', a term that encompasses all of lowland tropical South America. The ideas of Betty Meggers (1971, revised 1996) long dominated thinking about human/ environment interactions in this region. Her view was that environmental constraints, primarily the limitations on agriculture imposed by the nutrientpoor, highly weathered soils that characterize much of the lowland tropics, limited the density and social complexity of pre-Columbian populations, so that these were concentrated in areas of younger, richer alluvial soil along the major rivers, with only sparse populations of semi-nomadic slashand-burn farmers/foragers in interfluvial areas.

E-mail: doyle.mckey@cefe.cnrs.fr

ORCID: https://orcid.org/0000-0002-7271-901X
However, a flood of archaeological studies over the past 30 years has provided much evidence that at least some areas of interfluvial forest, as well as many of the seasonally flooded savannas around the margins of Amazonia, supported dense preColumbian populations that had lasting ecological impacts. How widespread such impact was is still controversial. While there is evidence that humans altered the composition of vegetation in many wellstudied 'permanent plots' (Levis et al. 2017), there is also evidence that archaeological sites are overrepresented in this set of plots (McMichael et al. 2017).

Knowing the human history of Amazonia is important for many reasons. If forests and savannas still bear an ecological legacy of past occupation, we need to know the nature of this legacy: why it has lasted so long after the collapse of Amerindian populations caused by Europeans and their infectious diseases, and how environments may 
change in the future as this legacy diminishes. Understanding how Amazonian biodiversity persisted despite substantial pre-Columbian human impact may also give insight into how resilience can be achieved today.

\section{WIDESPREAD PRE-COLUMBIAN HUMAN OCCUPATION OF AMAZONIA: LEGACIES IN SOILS}

Evidence of widespread human occupation of Amazonia came first from peri-Amazonian seasonally flooded savannas, where impacts on landscapes could be directly observed in aerial photographs (Figure 1, left panel). Vestiges of extensive wetland raised-field agriculture were found in many regions, from the Guianas coast to the Bolivian Llanos (Denevan 2001). Numerous other human-made landscape features continue to be documented in savannas, including humanmade forest islands (Lombardo et al. 2013) (Figure 1, right panel), canals, causeways and earthen fish weirs (Erickson 2000, Blatrix et al. 2018) (Figure $2)$. Later, aerial and satellite imagery showed other landscape features, such as ring ditches and geoglyphs, in recently deforested areas in southwestern Amazonia (Watling et al. 2017). With the application of LIDAR in Amazonian archaeology, such features can now be detected

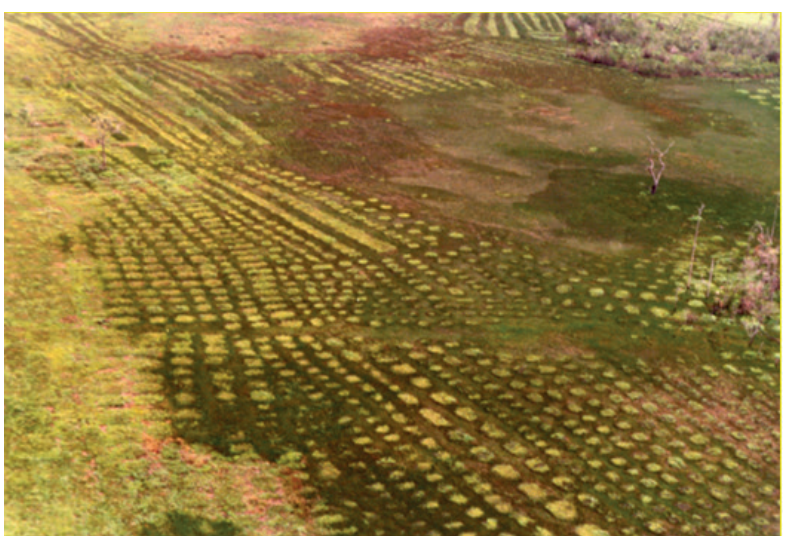

under intact forest canopy. For example, the detection by LIDAR of numerous ring ditches ('montagnes couronnées') in forests of French Guiana (Odonne and Molino 2018) shows that human occupation was far from negligible even in the highly weathered soils of the Guiana shield, where the ideas of Meggers (1971, revised 1996) would suggest that human densities should be sparsest.

Identification of these structures showed that even 'scratching the surface' could reveal evidence of human occupation of unexpected geographic breadth. But the impact of human occupation on ecological processes only became clear when archaeologists and soil scientists began to dig beneath the surface, to find that long periods of pre-Columbian human occupation had in many areas transformed the properties of Amazonian soils. The red and yellow soils that cover much of the lowland tropics are heavily weathered, acid, nutrient-poor oxisols. They are characterized by low nutrient content and by dominance of clays such as kaolinite that have very low cation exchange capacity, reducing their ability to retain nutients against leaching. However, Amazonia also holds large areas of darker soils called terra preta do indio (black soils) and terra mulata (brown soils). These soils, now grouped together

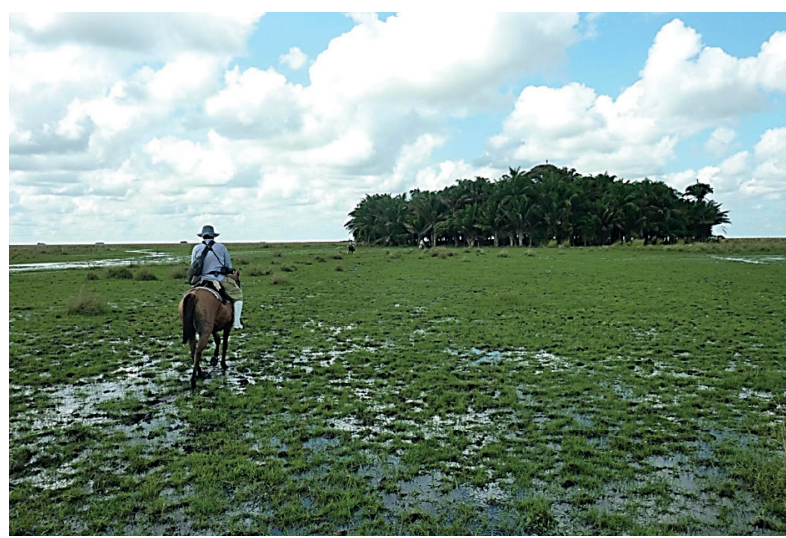

Figure 1 - Examples of the lasting ecological legacy left by pre-Columbian Amazonians in seasonally flooded savannas. Left panel: pre-Columbian wetland raised fields in seasonally flooded coastal savannas in French Guiana. Photo courtesy of Stéphen Rostain, CNRS, Paris, France. Right panel: A human-made forest island in seasonally flooded savanna in the Llanos de Mojos, Bolivia. Photo by the author. 

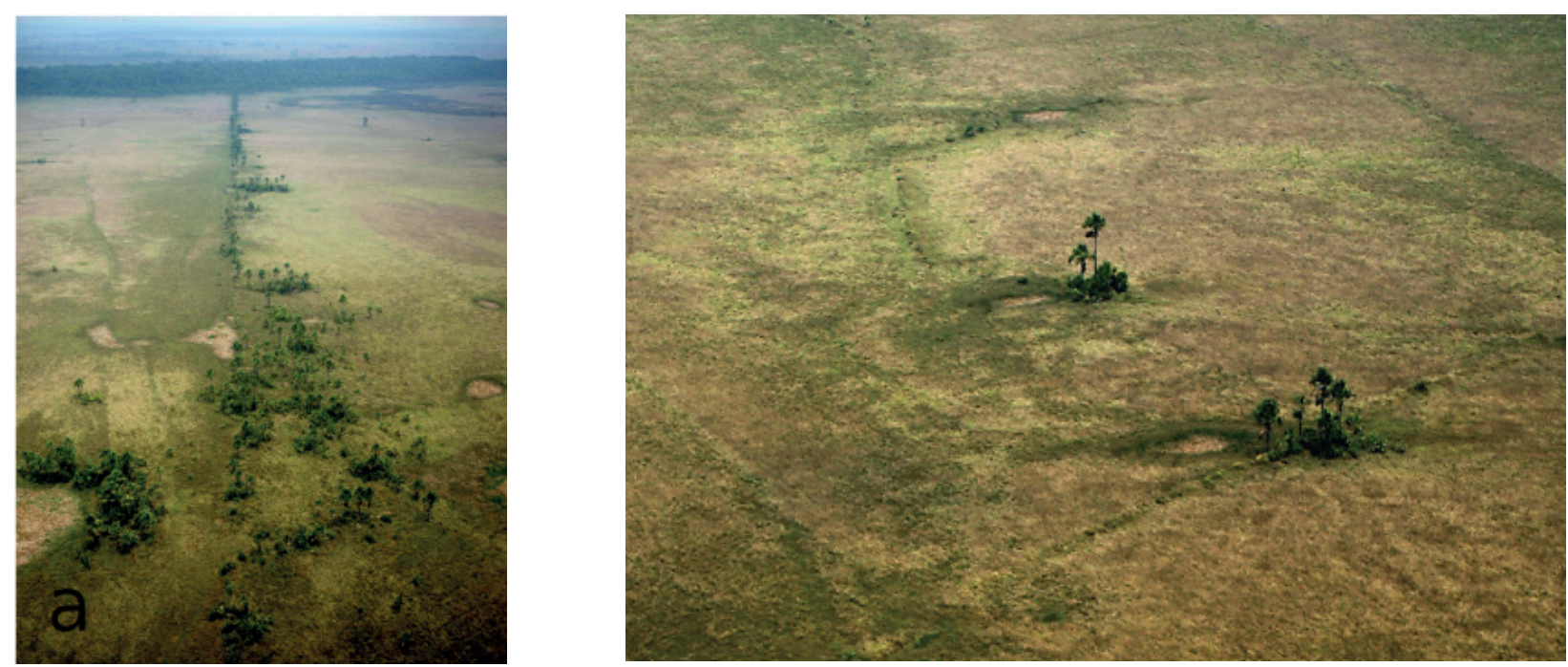

Figure 2 - Left panel: Vestige of a human-made earthen causeway built across a seasonally flooded savanna, from one area of welldrained forest to another, near Baures, in the Llanos de Mojos, Bolivia. Right panel : Vestige of a pre-Columbian earthen fish weir (V-shaped earthworks joined by linear dikes) in the same site. See Blatrix et al. (2018) for more information about this site. Both photos courtesy of Bruno Roux, Société Avion Jaune.

as Amazonian Dark Earths (ADEs), are plainly derived from oxisols and clearly result from longterm occupation by humans (Glaser and Birk 2012). Terra preta usually includes large amounts of ceramic fragments (Figure 3). Although most of these soils have been abandoned for over 500 years, they are to this day much more fertile than adjacent oxisols. Their fertility is explained partly by the fact that humans deposited nutrients on them from many sources (from kitchen wastes to dung), but above all by their high content of black carbon (charcoal, reworked by soil organisms to tiny fragments), whose oxidized surfaces provide sites that retain nutrient ions. Charcoal has in effect replaced clay in the soil's capacity to retain nutrients and supply them to plants. Because the polyaromatic compounds that comprise black carbon are a very stable form of organic matter, pre-Columbian human occupation permanently transformed the chemical properties of these soils, making them much more favorable for agriculture (Glaser et al. 2001).

Did the construction of raised fields in seasonally flooded savannas around the rim of
Amazonia also confer a lasting ecological legacy on soils? In coastal savannas of French Guiana, 'soil engineer' animals such as ants, termites and earthworms concentrate their activities on abandoned raised fields, because these are the only sites where, during the rainy season, ant and termite colonies can escape drowning and earthworms can come to the surface and respire between bouts of feeding in the waterlogged soils. The material brought by engineers to these sites-organic matter brought by ants and termites to their nests, soil deposited in casts by earthworms when they reach the surface - replace material lost to erosion. Furthermore, the porosity and the water-stable aggregates created by these animals and by plant roots help stabilize the soils on abandoned raised fields, further diminishing erosion. Engineers attracted to human-made elevated structures thus drive positive feedbacks that maintain these elevated structures against erosion. In effect, reworking of a flat landscape by humans pushed the ecosystem into an alternative stable state (McKey et al. 2010): after being abandoned, the landscape did not return to an initial flat state, rather the 


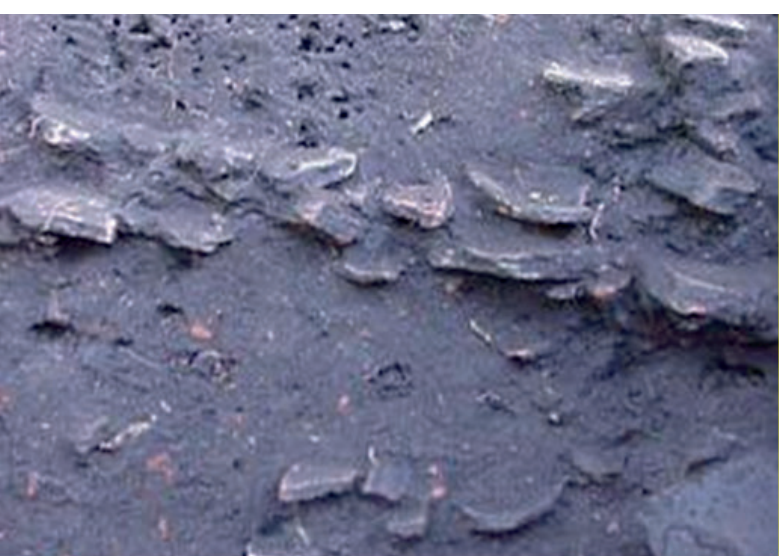

Figure 3 - Nutrient-enriched terra preta soil, rich in black carbon (charcoal) and ceramic fragments, resulting from longterm human occupation, beneath a forest in Brazil. Photo courtesy of Bruno Glaser, University of Halle-Wittenberg, Halle, Germany.

human-made topographic heterogeneity persisted. Humans thus exerted a lasting ecological legacy that is transmitted over centuries by the effects of their actions on soil engineers.

In this case, the legacy transmitted by soil engineers is 'positive', in terms of its effect on soil processes. Lacking black carbon, soils of abandoned raised fields in French Guiana do not retain high concentrations of nutrients, as do ADEs in forested Amazonia, but they do maintain favorable soil structure and high soil biodiversity. However, in other sites the legacy of soil engineers is not always positive. In the Bolivian llanos, termite colonies establish preferentially on raised fields (D. McKey, unpublished observations), as in the French Guianan coastal savannas. However, in some cases these termites are soil-compacters. They bring clay-rich subsoil to the surface, creating rock-hard termitaria that are resistant not only to erosion, but also to colonization by other organisms, including plants. In these landscapes, the abandoned raised fields are the 'worst' soils in the landscape, in terms of soil structure, fertility and biodiversity. Thus, like ADEs, soils of pre-Columbian raised fields show lasting legacies of human occupation, but these legacies depend on different mechanisms, affect different soil properties, and their effects are not always 'positive'.

\section{LEGACIES IN PLANT COMMUNITIES}

Pre-Columbian occupants not only altered soils, they also altered the plant communities growing on them. By removing non-useful plants, by attracting non-human dispersers of useful plants (e.g., agouti and paca) and by protecting, transporting and planting useful plants (e.g., Bertholletia), humans enriched the capacity of forests to provide food, both plants and animals, for them (Levis et al. 2018). Humans also selected desirable phenotypes of plants, culminating in the domestication of many plant species. Whereas crop diversity in Amazonia is centered in the basin, most crops were originally domesticated in numerous areas broadly scattered around the rim of Amazonia. Most domestication occurred long before the agricultural expansion, which may have depended on assembling crop combinations (Clement et al. 2010).

\section{THE LEGACIES OF MEGAFAUNAL EXTINCTIONS: CONNECTING THE HOLOCENE WITH THE PLEISTOCENE}

Most work on pre-Columbian human/environment interactions in Amazonia has dealt only with the last 4000 years, i.e., the late Holocene. However, humans have been in Amazonia since at least 13,500 years, and still-controversial evidence suggests they arrived in the region much earlier (Vialou et al. 2018). A better understanding of human/environment interactions requires taking historical ecology much deeper in time, connecting the Holocene with the Pleistocene. This is because increasing evidence points to the greater role of humans than of climate change as a cause of the ecological revolution that characterized the end of the Pleistocene: the extinction of megafauna (Araujo et al. 2017). Megafaunal extinction was particularly severe in South America. For example, 
of 20 Pleistocene megaherbivores on the continent, all became extinct at the end of the Pleistocene or during the early Holocene (Svenning and Faurby 2017). Although it is uncertain when humans first arrived in South America, we know that when they did, they exploited megafauna. For example, the Taima-Taima site in Venezuela features a projectile point showing wear that was found in situ associated with the pelvis of a juvenile mastodon (Gruhn and Bryan 1989).

What were the consequences of megafaunal loss for biodiversity? There were documented co-extinctions of other animals dependent on megafauna, including vultures, giant vampire bats, and dung beetles, and drastic range reductions of others. Although few plants appear to have suffered extinction with the loss of megafauna, the ecologies of many species were dramatically altered (Galetti et al. 2018). The disappearance of megafauna made many plant species 'anachronisms', with 'overbuilt' fleshy fruits for now-extinct fruit-eating megafauna and 'overbuilt' mechanical defenses (spines) against giant herbivores that no longer exist (Janzen and Martin 1982). Work has concentrated on the 'megafaunal dispersal syndrome', examining the ecologies of plants whose principal seed-dispersing animals disappeared at the end of the Pleistocene (Guimarães et al. 2008). A striking trait common to these plants is that fruits when mature fall to the ground, presented to terrestrial mammals. Many go uneaten and rot. For some tree species, smaller animals, such as rodents, can assure some dispersal services, but dispersal distances are much shorter than would be the case were seeds dispersed by larger animals, with their greater gut capacities, longer seed retention times and longer distances moved (Pires et al. 2018). Loss of dispersal services reduces the plant's ability to escape seed-destroying animals and pathogens, which are densest near the parent tree, and to colonize new sites.

In many cases, humans have come to the rescue, saving many plants from drastic range reduction or even extinction. Many of the fruits that megafauna ate are also appreciated by humans. These include cacao, cupuaçu, soursop and many others. Wild megafaunal species whose fruits are eaten by humans today have larger geographic ranges than those not eaten by humans; megafaunal species that are cultivated by humans have even larger ranges (van Zonneveld et al. 2018).

Cucurbita is a particularly well-studied example, showing how domestication enabled a particularly megafaunal-dependent group to escape probable near-extinction (Kistler et al. 2015). Fruits of wild Cucurbita contain high concentrations of cucurbitacins, which are bitter and toxic triterpenoids. The fruits of wild cucurbits are not eaten by small mammals, but large numbers of seeds have been recovered from mastodon dung. Larger herbivores appear to have greater capacity to detoxify these and other bitter-tasting plant chemical defenses. Large animals' greater tolerance of such compounds means that they are less faced by selective pressure to detect and avoid them, explaining why there is a negative correlation in mammals between body size and the diversity of the repertoire of bitter taste receptors (Kistler et al. 2015). Past distributions of wild Cucurbita spp. were larger than their present distributions, as illustrated, for example, by the highly fragmented distribution of species such as C. okeechobensis, found today only in an area within central Florida and another area in Veracruz, Mexico. When megaherbivores disappeared, cucurbits lost their sole effective dispersal agents. A few species, such as $C$. pepo and C. moschata, were saved from extinction by humans, who domesticated them, selecting for lower cucurbitacin content. These two species are today unknown in the wild.

As already noted above, many other megafaunal fruits have prospered because of humans. Much later, introduced domesticated animals began to play important roles in dispersing megafaunal fruits such as Samanea saman (dispersed by cattle) 
and Crescentia cujete (dispersed by horses) (Janzen and Martin 1982).

Seeds are not the only things that megafauna moved. For the same reasons they move seeds farther, megafauna also drive lateral movement of nutrients. Doughty et al. (2013) modelled the consequences of the disappearance of megafauna for the distribution of levels of phosphorus (P) in Amazonia. Levels of this nutrient in soil are highest in western Amazonia, replenished by erosion of the Andes, and in the alluvial soils along the Amazon. When megafauna were present, their movement of materials redistributed $\mathrm{P}$ into the weathered terra firme soils of central and eastern Amazonia. With the disappearance of megafauna, less $\mathrm{P}$ is redistributed and $\mathrm{P}$ levels in these soils are lower. Their model projects that this lowering will continue until a new steady state is reached in 25,000 years. Their results imply that levels of this major limiting nutrient are declining and will continue to do so for a long time, with effects expected on the functioning of natural ecosystems and the productivity of agriculture. These changes in terrestrial ecosystems are just one manifestation of the global changes in nutrient redistribution caused by humans, who have hunted to near-extinction the principal nutrient-moving animals throughout the planet, not only terrestrial megafauna but also marine megafauna and anadromous fish (Doughty et al. 2016).

\section{CONNECTING HISTORICAL ECOLOGY WITH BIOLOGICAL AND CULTURAL EVOLUTION}

We can gain in understanding human/environment interactions by taking historical ecology even deeper in time beyond the Pleistocene, by connecting historical ecology with evolutionary processes. How plants evolve under domestication has been extensively studied, particularly in response to direct human selection for attributes such as yield. However, for many plants how selection exerted by humans interacts with selective forces that have acted on plants throughout their history, and that continue to act upon them in domesticated environments, has not been investigated (McKey et al. 2012). Studies of chili (Capsicum spp.) offer an illustrative example (Tewksbury et al. 2008). In the dry tropical forests of the Chiquitanía in Bolivia, fruits of Capsicum chacoense are often attacked by lygaeid bugs. Sites where fruits have been pierced by a bug's proboscis permit the easy entry of a fungal pathogen that kills the seeds. Capsaicinoids, the compounds that give chili its pungency, protect the fruits against fungal attack. Such selective pressures have given us pungent chilies. Interestingly, humans use capsaicinoids and other plant-defensive compounds found in spices for the same function that they perform in wild Capsicum. Spices, including chili, have strong antimicrobial properties. There is strong evidence that their principal function is to fight against bacterial contamination of cooked foods: " Humans have borrowed plants' evolutionary 'recipes' for evolutionary survival for use in cuisine to combat foodborne microorganisms and to reduce food poisoning." (Sherman and Billing 1999). The quantities and diversity of spices used in traditional cuisines, and their antimicrobial effects, show latitudinal gradients: spice use is greatest in tropical climates, where cooked food is more rapidly contaminated by bacteria (Sherman and Billing 1999). Comparing recipes of the same country, more spice is used in meat recipes than in vegetable recipes, because unlike plants, animals lose their defenses (immunity) at death, so that meat dishes are more rapidly contaminated (Sherman and Hash 2001). These patterns are repeated all over the world, showing convergent cultural evolution in response to similar selective pressures. This pattern has never been explored for traditional cuisines of Amazonia. Functional analyses of Amazonian diets could be very instructive. 
CONNECTING THE PAST AND THE PRESENT WITH THE FUTURE

Not only must historical ecology be extended to deeper in the past, it must also be connected to the present and the future: Pleistocene, Holocene and Anthropocene must all be integrated as a single continuous history. An example of why this is important is offered by work on carbon dynamics of Amazonian forests. Amazonian forests are currently a carbon sink, helping to minimize global greenhouse gas emissions, but this carbon sink is weakening, owing to greater rates of tree mortality. As trees die and are replaced at faster rates (Phillips and Gentry 1994), more $\mathrm{CO}_{2}$ is emitted and less is stored. Understanding present and future dynamics of carbon - and of forests - depends on understanding why this is happening.

One hypothesis to account for higher tree mortality is based on the history of preColumbian human occupation (Dull et al. 2010). According to this hypothesis, late-Holocene agricultural intensification in Amazonia (testified to by increasing amounts of soil charcoal from anthropogenic fire) led to reduction of forest cover. Then, as populations collapsed after the European contact, forests regrew. Again according to this hypothesis, much of Amazonia is now 500-yearold secondary forest, still growing, still storing net amounts of carbon. However, these old secondary forests are now reaching maturity : more trees are dying, and greater turnover is leading to lower carbon storage.

However, there are alternative hypotheses based on current global changes. According to one hypothesis, the greatly increased levels of atmospheric $\mathrm{CO}_{2}$ over the past decades are leading to increased tree growth. But increased growth might also decrease tree longevity, either by a direct trade-off or indirectly, for example, by favoring faster-growing plant species such as shortlived pioneer trees and lianas (Bugmann and Bigler
2011). Densities of lianas are increasing in many Amazonian forests (Phillips et al. 2002). Heavy liana loads cause trees to fall, forming more gaps that are colonized by short-lived pioneer trees. All these factors lead to greater turnover, decreased carbon residence time and greater $\mathrm{CO}_{2}$ emission. As shown by a recent review, the jury is still out on the question of the causes of recent increased tree mortality in tropical forests (McDowell et al. 2018).

\section{CONCLUSIONS}

Humans have affected Amazonian landscapes for a very long time. Teasing apart their different impacts at different scales of time, from the Pleistocene through to the continuing Anthropocene, may not be easy, but understanding the dynamics of biodiversity and ecosystem functioning requires that we do it. We must also take an increasingly analytical approach. For example, perhaps more important than studying the impacts of humans on species composition and relative abundances in tree communities is studying the impacts of these compositional changes on ecosystem functioning: Did human-encouraged species share functional traits that led to altered functioning of humanaltered forest? With this and many other questions still open, studying the past and its present-day ecological legacies should have an interesting and useful future.

\section{ACKNOWLEDGMENTS}

My group's research on the themes developed in this paper has been funded by grants from the Institut Universitaire de France, the Institut Ecologie et Environnement (INEE)/CNRS (Projets Exploratoires Pluridisciplinaires program), the Mission pour l'Interdisciplinarite of the CNRS, the TOSCA committee (Terre Solide, Océan, Surfaces Continentales, Atmosphère) of the CNES (French National Center for Space Research) and the 
Groupement de Recherche Mosaïque (GDR 3353, INEE/CNRS). Many colleagues at CEFE and our research partners have contributed to this research. I cannot mention them all, but particular recognition must be given to Rumsaïs Blatrix, Delphine Renard, Anne Zangerlé and Leonor Rodrigues.

\section{REFERENCES}

ARAUJO BBA, OLIVEIRA-SANTOS LGR, LIMARIBEIRO MS, DINIZ-FILHO JAF AND FERNANDEZ FA. 2017. Bigger kill than chill: The uneven roles of humans and climate on late Quaternary megafaunal extinctions. Quatern Int 431: 216-222.

BLATRIX R ET AL. 2018. The unique functioning of a preColumbian Amazonian floodplain fishery. Sci Rep-UK 8: 5998.

BUGMANN H AND BIGLER C. 2011. Will the $\mathrm{CO}_{2}$ fertilization effect in forests be offset by reduced tree longevity? Oecologia 165: 533-544.

CLEMENT CR, CRISTO-ARAÚJO D, COPPENS D'EECKENBRUGGE G, ALVES PEREIRA A AND PICANÇO-RODRIGUES D. 2010. Origin and domestication of native Amazonian crops. Diversity 2: 72106.

DENEVAN WM. 2001. Cultivated landscapes of native Amazonia and the Andes. Oxford, UK: Oxford University Press, $396 \mathrm{p}$.

DOUGHTY CE, ROMAN J, FAURBY S, WOLF A, HAQUE A, BAKKER ES, MALHI Y, DUNNING JR. JB AND Svenning JC. 2016. Global nutrient transport in a world of giants. P Natl Acad Sci USA 113: 868-873.

DOUGHTY CE, WOLF A AND MALHI Y. 2013. The legacy of the Pleistocene megafauna extinctions on nutrient availability in Amazonia. Nat Geosci 6: 761-764.

DULL RA, NEVLE RJ, WOODS WI, BIRD DK, AVNERY S AND DENEVAN WM. 2010. The Columbian Encounter and the Little Ice Age: Abrupt land use change, fire, and greenhouse forcing. Ann Assoc Am Geogr 100: 755-771.

ERICKSON CL. 2000. An artificial landscape-scale fishery in the Bolivian Amazon. Nature 408: 190-193.

GALETTI M ET AL. 2018. Ecological and evolutionary legacy of megafauna extinctions. Biol Rev 93: 845-862.

GLASER B AND BIRK JJ. 2012. State of the scientific knowledge on properties and genesis of Anthropogenic Dark Earths in Central Amazonia (terra preta de Índio). Geochim Cosmochim Acta 82: 39-51.

GLASER B, HAUMAIER L, GUGGENBERGER G AND ZECH W. 2001. The Terra Preta phenomenon. A model for sustainable agriculture in the humid tropics. Naturwissenschaften 88: 37-41.
GRUHN R AND BRYAN AL. 1989. The record of Pleistocene megafaunal extinction at Taima-Taima, northern Venezuela. In: Martin PS and Klein RG (Eds), Quaternary extinctions: a prehistoric revolution, Tucson: University of Arizona Press, p. 128-139.

GUIMARÃES JR PR, GALETTI M AND JORDANO P. 2008. Seed dispersal anachronisms: Rethinking the fruits extinct megafauna ate. PLoS One 3: e1745.

JANZEN DH AND MARTIN PS. 1982. Neotropical anachronisms: The fruits the gomphotheres ate. Science 215: 19-27.

KISTLER L, NEWSOM LA, RYAN TM, CLARKE AC, SMITH BD AND PERRY GH. 2015. Gourds and squashes (Cucurbita spp.) adapted to megafaunal extinction and ecological anachronism through domestication. P Natl Acad Sci USA 112: 15107-15112.

LEVIS C ET AL. 2017. Persistent effects of pre-Columbian plant domestication on Amazonian forest composition. Science 355: 925-931.

LEVIS C ET AL. 2018. How people domesticated Amazonian forests. Front Ecol Evol 5: 171.

LOMBARDO U, SZABO K, CAPRILES JM, MAY JH, AMELUNG W, HUTTERER R, LEHNDORFF E, PLOTZKI A AND VEIT H. 2013. Early and middle Holocene hunter-gatherer occupations in Western Amazonia: the hidden shell middens. Plos One 8: e72746.

MCDOWELL N ET AL. 2018. Drivers and mechanisms of tree mortality in moist tropical forests. New Phytol 219: 851-869.

MCKEY D, ELIAS M, PUJOL B AND DUPUTIÉ A. 2012. Ecological approaches to crop domestication. In: Gepts P, Bettinger R, Brush SB, Famula T, Mcguire PE, Qualset $\mathrm{CO}$ and Damania AB (Eds), Biodiversity in agriculture: Domestication, evolution and sustainability, Cambridge, UK: Cambridge University Press, p. 377-406.

MCKEY D, ROSTAIN S, IRIARTE J, GLASER B, BIRK JJ, HOLST I AND RENARD D. 2010. Pre-Columbian agricultural landscapes, ecosystem engineers, and selforganized patchiness in Amazonia. P Natl Acad Sci USA 107: 7823-7828.

MCMICHAEL CN, MATTHEWS-BIRD F, FARFAN-RIOS W AND FEELEY KJ. 2017. Ancient human disturbances may be skewing our understanding of Amazonian forests. P Natl Acad Sci USA 114: 522-527.

MEGGERS B. 1971. Revised 1996. Amazonia: Man and culture in a counterfeit paradise. Washington, D.C.: Smithsonian Institution, $214 \mathrm{p}$.

ODONNE G AND MOLINO J-F. 2018. Écologie historique amazonienne, une interdisciplinarité nécessaire. Quand l'archéologue est perdu dans les bois.... Les nouvelles de l'archéologie 152: 11-15.

PHILLIPS OLAND GENTRY AH. 1994. Increasing turnover through time in tropical forests. Science 263: 954-958. 
PHILLIPS OL ET AL. 2002. Increasing dominance of large lianas in Amazonian forests. Nature 418: 770-774.

PIRES MM, GUIMARÃES PR, GALETTI M AND JORDANO P. 2018. Pleistocene megafaunal extinctions and the functional loss of long-distance seed-dispersal services. Ecography 41: 153-163.

SHERMAN PW AND BILLING J. 1999. Darwinian gastronomy: why we use spices. BioScience 49: 453-463.

SHERMAN PW AND HASH GA. 2001. Why vegetable recipes are not very spicy. Evol Hum Behav 22: 147-163

SVENNING J-C AND FAURBY S. 2017. Prehistoric and historic baselines for trophic rewilding in the Neotropics. Perspect Ecol Conserv 15: 282-291.

TEWKSBURY JJ, REAGAN KM, MACHNICKI NJ, CARLO TA, HAAK DC, PEÑALOZA ALC AND
LEVEY DJ. 2008. Evolutionary ecology of pungency in wild chilies. P Natl Acad Sci USA 105: 11808-11811.

VAN ZONNEVELD M, LARRANAGA N, BLONDER B, CORADIN L, HORMAZA JI AND HUNTER D. 2018. Human diets drive range expansion of megafaunadispersed fruit species. P Natl Acad Sci USA 115: 33263331.

VIALOU D, BENABDELHADI M, FEATHERS J, FONTUGNE M AND VIALOU AV. 2018. Peopling South America's centre: the late Pleistocene site of Santa Elina. Antiquity 91: 865-884.

WATLING J, IRIARTE J, MAYLE FE, SCHAAN D, PESSENDA LC, LOADER NJ, STREET-PERROTT FA, DICKAU RE, DAMASCENO A AND RANZI A. 2017. Impact of pre-Columbian "geoglyph" builders on Amazonian forests. P Natl Acad Sci USA 114: 1868-1873. 